\title{
BUDIDAYA UDANG VANAME SISTEM BIOFLOK
}

\author{
Brata Pantjara, Agus Nawang, Usman, dan Rachmansyah \\ Balai Riset Perikanan Budidaya Air Payau \\ Jl. Makmur Dg. Sitakka No. 129, Maros, Sulawesi Selatan 90512 \\ E-mail: bpantjara@yahoo.com
}

\begin{abstract}
ABSTRAK
Problem utama pada budidaya tambak udang intensif adalah menurunnya kualitas air yang layak selama pemeliharaan udang dan munculnya penyakit. Upaya mengurangi permasalahan tersebut adalah pemanfaatan bioflok di tambak. Bioflok merupakan campuran dari berbagai mikroba, fitoplankton, zooplankton, protozoa, detritus, partikel organik. Teknologi bioflok dapat meningkatkan kualitas air, meminimalkan pergantian air (tanpa pergantian air), efisiensi pakan, dan menghambat berkembangnya penyakit selama budidaya. Budidaya udang vaname intensif sistem bioflok dengan padat penebaran 100 ekor $/ \mathrm{m}^{2}$ selama 95 hari diperoleh produksi sebesar $10,375 \mathrm{~kg} / \mathrm{ha}$ (FCR 1,3) dan tanpa bioflok 9,176 $\mathrm{kg} / \mathrm{ha}$ (FCR 1,6).
\end{abstract}

KATAKUNCl: vaname, bioflok

\section{PENDAHULUAN}

Pemerintah melalui Kementerian Kelautan dan Perikanan (KKP) menargetkan kenaikan terhadap produksi udang sebesar $74,75 \%$ di tahun $2010-2014$, yaitu dari 400.000 ton menjadi 699.000 ton. Dalam pencapaian target tersebut, peningkatan produksi udang akan diarahkan pada udang windu (Penaeus monodon) dan vaname (Litopenaeus vannamei). Diharapkan peningkatan produksi ini diperoleh dari budidaya udang secara ekstensif hingga intensif. Udang vaname sebagai salah satu komoditas introduksi di Indonesia yang beberapa tahun terakhir mengalami perkembangan cukup pesat diharapkan dapat menggantikan sementara udang windu dan memberikan andil terhadap perolehan devisa negara setelah menurunnya produksi udang windu. Seringnya terjadi kematian udang pada budidaya ekstensif hingga intensif disebabkan adanya serangan penyakit terutama virus antara lain: WSSV, TSV, IMNV, LVNV, IHHNV, dan bakteri Vibrio harveyi. Secara alami diketahui bahwa laju infeksi penyakit virus disebabkan sanitasi lingkungan dan menurunnya kualitas lingkungan baik secara internal dan eksternal terutama pengaruh limbah budidaya yang dapat mencemari lingkungan sekitarnya. Berkembangnya virus IM NV (Infectious M yo Necrosis Virus) pada udang vaname dapat menyebabkan kematian udang secara massal. Penyakit ini muncul karena kondisi lingkungan tambak terutama salinitas, suhu, dan kualitas pakan rendah. Gejala serangan khas, pangkal ekor berubah merah dan secara bertahap terjadi kematian di dasar tambak. Penyakit Myo disebabkan oleh virus jenis RNA (Ribo Nucleic Acid). Virus tersebut tergolong ganas karena dapat mematikan vaname berumur 60-80 hari dalam waktu yang sangat cepat.

Untuk saat ini peningkatan produksi udang tidak akan dilakukan pada kebijakan perluasan areal, namun diutamakan pada pemanfaatan lahan yang ada dengan penggunaan teknologi yang tepat (Pantjara, 2008). Salah satu teknologi yang dapat dikembangkan untuk peningkatan produksi udang vaname tersebut adalah teknologi bioflok (Avnimelech, 2009). Di beberapa negara seperti Israel, Amerika Tengah, dan beberapa negara lainnya telah membuktikan keberhasilan teknologi bioflok baik untuk nila merah, udang vaname, dan udang windu (Avnimelech \& Ritvo, 2003). Budidaya udang vaname sistem bioflok di Indonesia telah dikembangkan di beberapa daerah di Indonesia beberapa tahun terakhir ini. Teknik bioflok dapat memberikan keuntungan terutama dalam mempertahankan kualitas air dan efisiensi pakan 10\% 20\%

Bioflok merupakan kumpulan atas berbagai mikroorganisme seperti bakteri, fungi, protozoa, fitoplankton, dan bahan organik dari limbah yang tidak terdekomposisi. Teknologi bioflok merupakan teknologi ramah lingkungan karena memanfaatkan bahan dari limbah dari sisa pakan yang ada menjadi pakan dari mikroba sehingga bahan dari limbah organik tersebut terdegradasi dan mikroba dapat berkembang membentuk sekumpulan mikroba yang bercampur dengan koloid organik lainnya (Burford et al., 2004; De Schryver et al., 2008). Menurut Avnimelech (2009), hasil perombakan tersebut jika terbentuk floks dapat digunakan udang dan menjadi sumber protein yang sangat baik bagi udang. Senyawa 

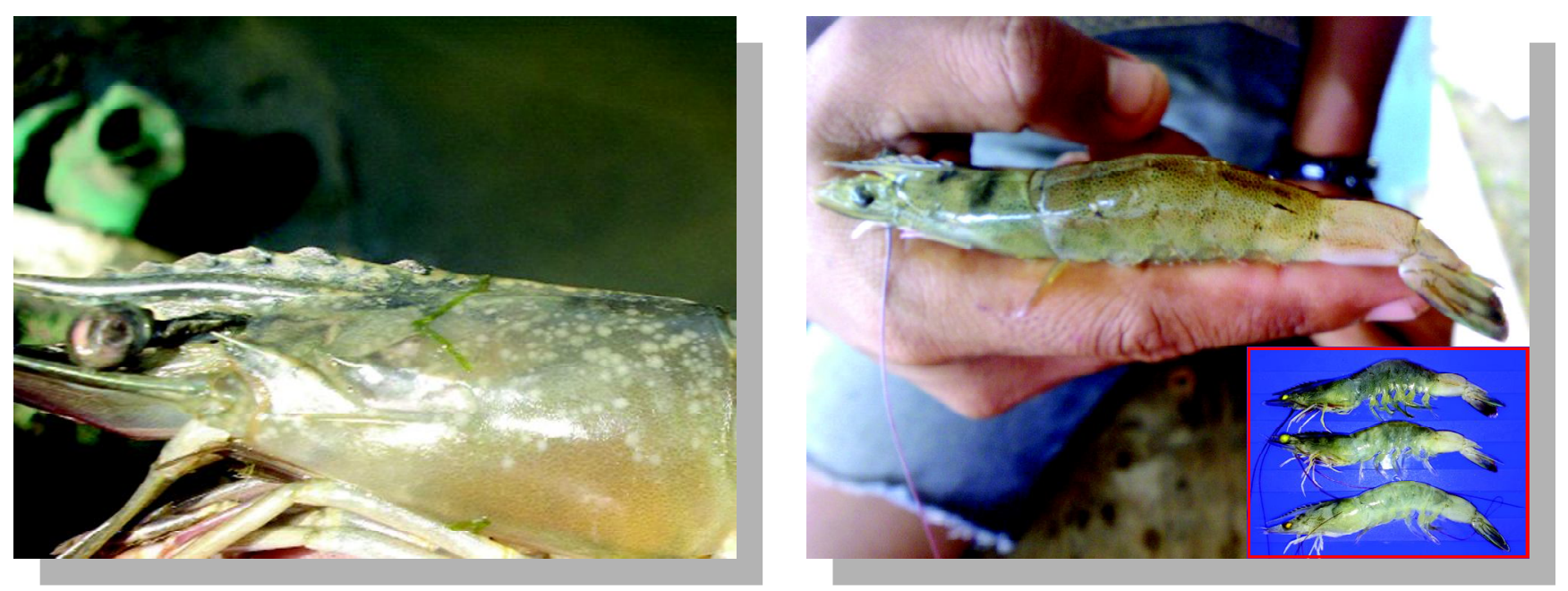

Gambar 1. Udang yang terserang penyakit WSSV (kiri) dan serangan IMNV (kanan)

organik yang terdekomposisi mengandung senyawa karbon $(\mathrm{C})$, hidrogen $(\mathrm{H})$, oksigen $\left(\mathrm{O}_{2}\right)$, nitrogen $(\mathrm{N})$ dengan sedikit fosfor (P) menjadi massa lumpur berupa biofloks dengan menggunakan bakteri pembentuk floks (Flocs Forming Bacteria).

Terbentuknya flok karena adanya bakteri yang mampu merombak limbah bahan organik sehingga bakteri tersebut berkembang dan masing-masing sel bakteri berperan mensekresikan lendir metabolit dan biopolimer (polisakarida, peptide, dan lipida) atau senyawa kombinasinya. Secara alami terjadi gaya tarik antar sel dari sel bakteri dan mikroorganisme serta organik lainnya yang membentuk flok yang banyak mengandung protein tinggi. Beberapa mikroorganisme berfungsi sebagai bioflocculant antara lain Zooglea ramigera, Paracolobacterium aerogenoids, Bacillus subtilis, Bacillus cereus, Flavobacterium, Pseudomonas alcaligenes, Sphaerotillus natans, Escherichia intermedia. Keberadaan oksigen dalam pembentukan bioflok mutlak diperlukan agar flok dapat terbentuk sempurna. Kekurangan oksigen dapat menyebabkan berkembangnya bakteri dan flok kurang terbentuk sempurna. Pada kondisi $\mathrm{pH}$ yang rendah dapat menghambat terbentuknya bioflok karena akan mengurangi kandungan kation divalen dalam air untuk ikatan esterase, untuk itu, pada $\mathrm{pH}$ yang rendah diperlukan pemberian dolomit agar pH menjadi netral. Hasil dekomposisi bahan organik menghasilkan amonia yang dapat menyebabkan toksik bagi udang, namun masih dapat dimanfaatkan bakteri dalam proses amonifikasi dan nitrifikasi sehingga kualitas air dapat lebih baik. Perkembangan pesat dari bakteri flok akan memungkinkan terjadinya gumpalan-gumpalan yang dapat dimanfaatkan kembali oleh biota. Namun demikian dibutuhkan kandungan oksigen yang cukup (> $4 \mathrm{mg} / \mathrm{L}$ ), pH 7,3-8,3 untuk mempertahankan flok karena susunan flok akan berubah kembali setelah 8 jam. Kebutuhan aerasi besar ini menyebabkan teknik bioflok hanya layak secara ekonomis untuk padat tebar tinggi.

\section{BEBERAPA FAKTOR YANG PERLU DIPERHATIKAN DALAM BUDIDAYA UDANG VANAME SISTEM BIOFLOK}

1. Konstruksi tambak sebaiknya tambak beton atau tambak plastik (HDPE) (Gambar 2). Konstruksi tambak dari tanah pembentukan bioflok kurang optimal karena pada tambak konstruksi tanah mempunyai kelemahan porositas tinggi sehingga harus menambah air dan bila dipasang kincir air yang cukup banyak menyebabkan sebagian tanah dasar teraduk dan merusakkan pematang tambak.

2. Limbah sisa pakan harus cukup tinggi (budidaya udang intensif), karena limbah pakan dapat menyediakan karbon dan nitrogen. Rasio (perbandingan unsur karbon $(\mathrm{C})$ dengan nitrogen $(\mathrm{N})$ atau $\mathrm{C} / \mathrm{N}$ rasio. Nilai ideal C:N rasio untuk bioflok 1:15 sampai 1:20 atau minimal 1:12. Secara alami rasio C/N dalam tambak kurang dari 12 sehingga perlu tambahan unsur karbon misalnya Molase.

3. Mengurangi pergantian air yang berlebihan karena dapat mempengaruhi keseimbangan unsur $\mathrm{C}$ dan $\mathrm{N}$. Selain itu, juga membuang bakteri yang sudah tumbuh dan sebaliknya kemungkinan masuknya bakteri negatif (patogen) dari luar.

4. Harus ada oksigen yang mencukupi baik untuk organisme budidaya juga organisme yang hidup di sekitarnya seperti bakteri, plankton, dan organisme lainnya. Kekurangan oksigen dapat berakibat fatal 


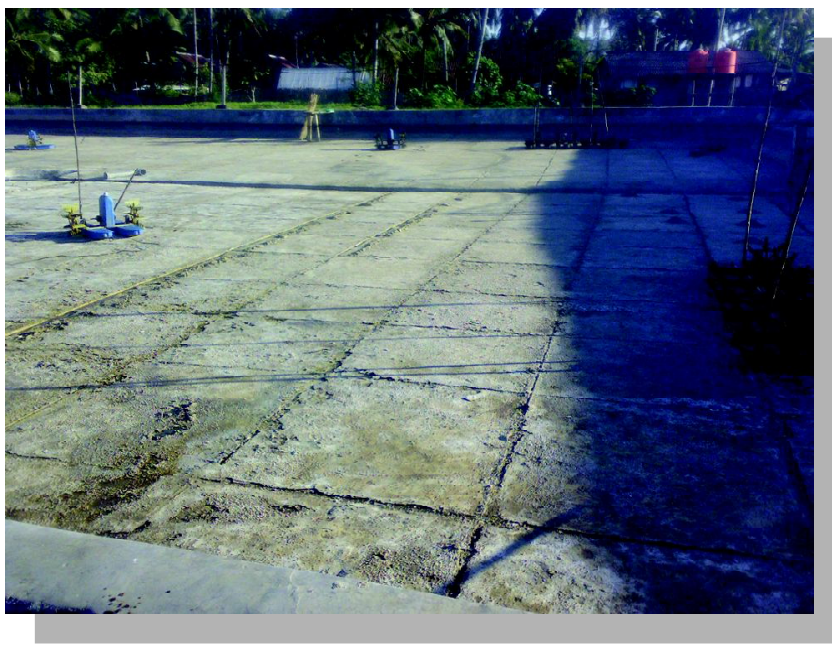

Konstruksi dasar tambak beton

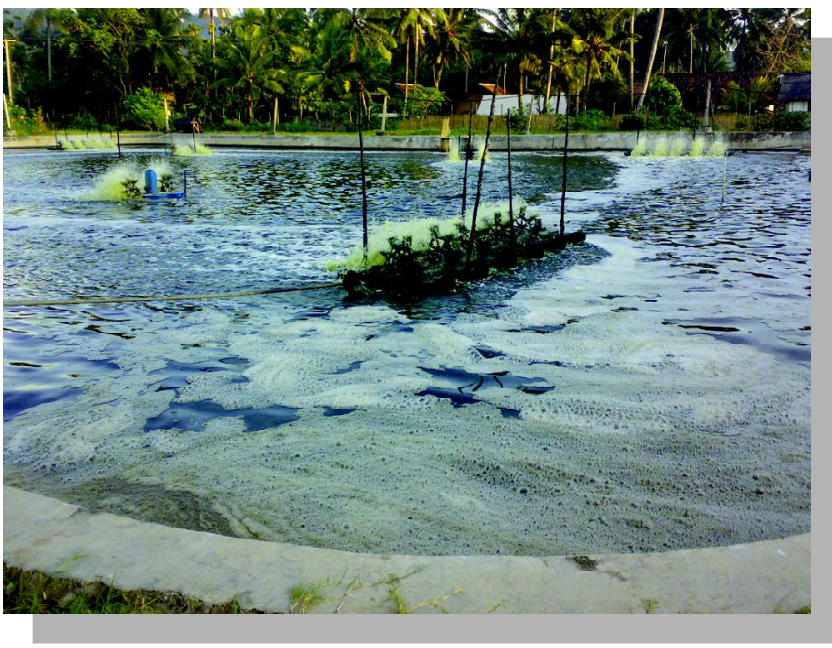

Penempatan/tata letak kincir

Gambar 2. Konstruksi tambak beton dan pemasangan kincir pada budidaya udang vaname sistem bioflok

karena menghasilkan senyawa amonia cukup tinggi dan toksik bagi udang sehingga menyebabkan kematian udang yang dibudidaya.

5. Penempatan kincir air harus tepat dalam proses pengadukan, dan distribusinya merata sehingga flok yang terbentuk dapat optimal. Terbentuknya flok didominasi oleh bakteri heterotrop. Pengadukan air dalam tambak melalui kincir air harus stabil dan hindari terjadinya titik mati pergerakan air karena bakteri tidak akan mampu mengubah limbah organik dalam air menjadi protein bakteri.

6. Kepadatan flok harus dimonitoring sehingga tidak terlalu padat, karena bila berlebihan dapat menurunkan kualitas flok. Kelebihan flok dapat dikurangi dengan pengenceran atau menyaring flok dengan membuang sebagian limbah pada dasar tambak melalui saluran pembuangan yang umumnya ditempatkan di saluran tengah (Central drain) (Gambar 3). Berdasarkan volumenya bioflok digolongkan padat bila volume flok dalam air mencapai $>20 \mathrm{~mL} / \mathrm{L}$, sedang bila volume flok mencapai 10-20 mL/L, rendah bila volume flok mencapai 1-10 mL/L dan sangat rendah bila volume flok mencapai $<1 \mathrm{~mL} / \mathrm{L}$.

7. Aplikasi dolomit dapat dilakukan bila terjadai penurunan $\mathrm{pH}$ air dalam tambak dan dosisnya 2-10 $\mathrm{mg} / \mathrm{L}$ atau tergantung pada seberapa besar penurunan pH air. pH air tambak stabil pada pH 7-8 dengan fluktuasi 0,02-0,2.
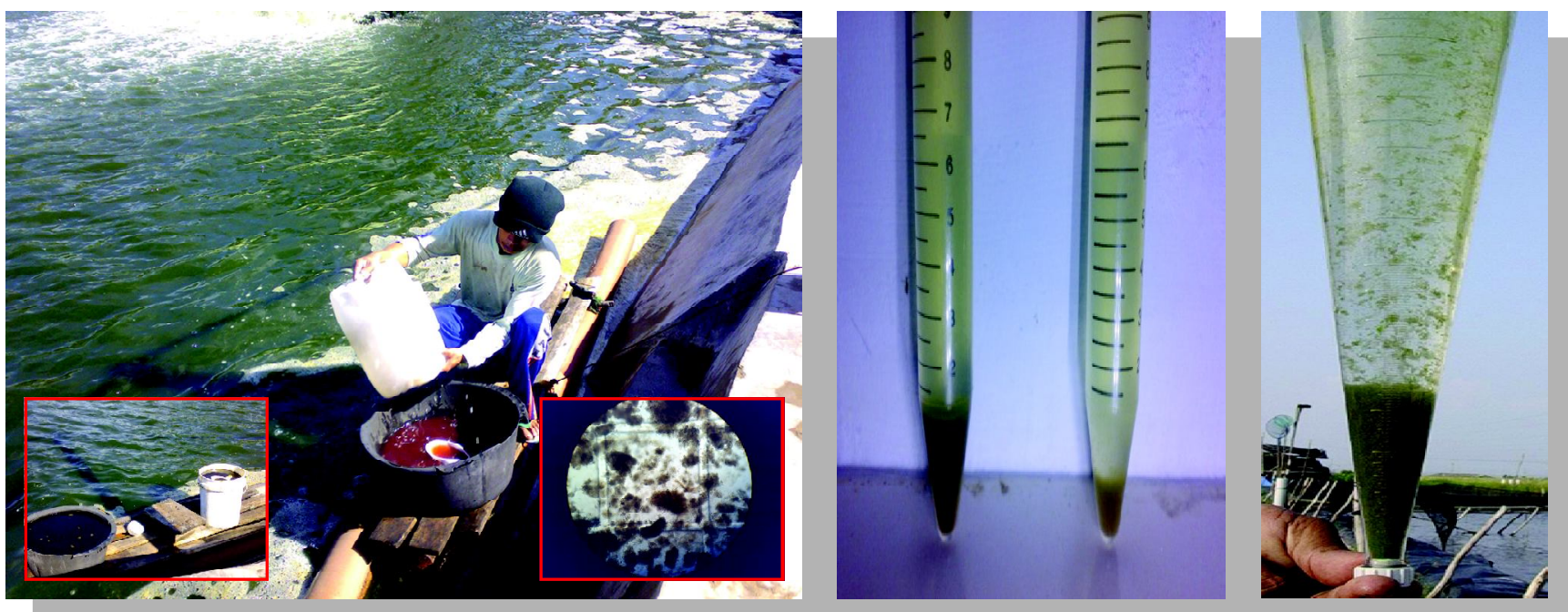

Gambar 3. Aplikasi molase di tambak dan flok yang terbentuk (kiri) dan volume flok pada tambak intensif (tengah dan kanan) 

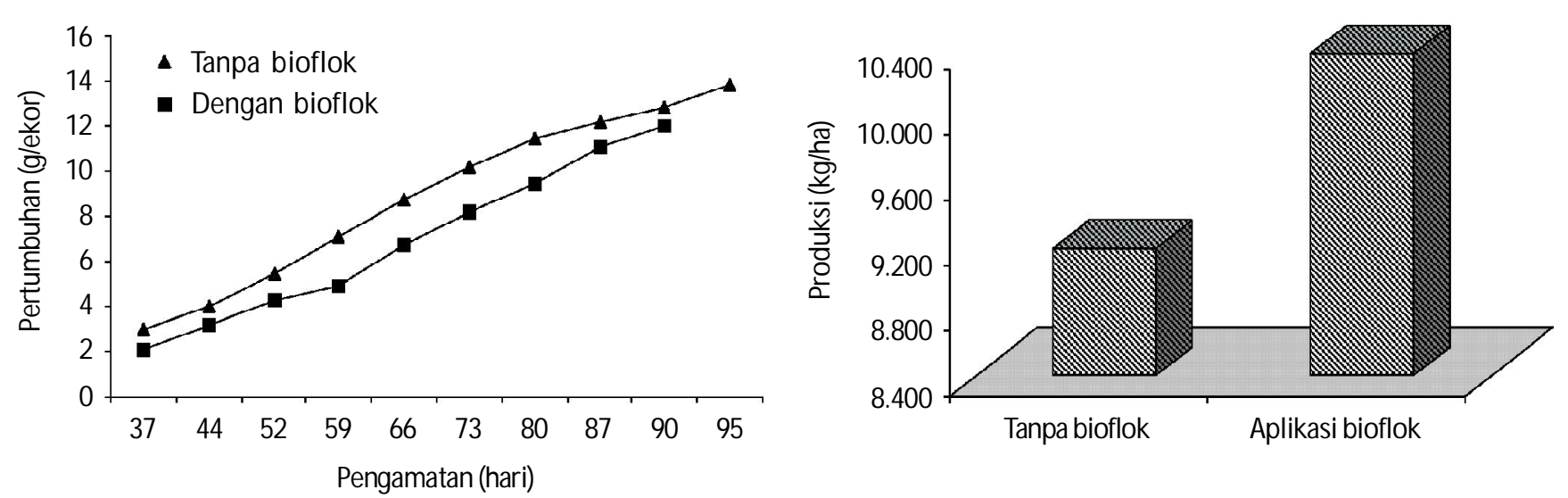

Gambar. 4. Pertumbuhan dan produksi udang vaname pada budidaya intensif sistem bioflok di Desa Hanura Kecamatan Pesawaran Provinsi Lampung

\section{PRODUKSI}

Budidaya udang vaname sistem bioflok di tambak intensif milik masyarakat telah dicoba oleh Balai Riset Perikanan Buididaya Air Payau Maros. Lokasi di Desa Hanura, Lampung Selatan. Dari hasil kegiatan tersebut diperoleh hasil bahwa perlakuan bioflok pada budidaya udang vaname intensif (padat penebaran $100 \mathrm{ekor} / \mathrm{m}^{2}$ ) selama 95 hari diperoleh produksi sebesar $10,375 \mathrm{~kg} / \mathrm{ha}$ (FCR 1,3) dan tanpa bioflok 9,176 kg/ha (FCR 1,6) (Gambar 4).

\section{KEBUTUHAN MOLASE SEBAGAI SUMBER C}

Untuk membentuk flok di tambak diperlukan sumber C tersedia seperti molase. Menurut Pantjara (2008), molase bermanfaat sebagai Priming effect, karena digunakan mikroorganisme untuk berkembang yang akhirnya dapat merombak limbah organik sisa pakan tersebut. Di tambak jumlah molase yang diberikan dapat diprediksi dengan mengestimasi jumlah limbah terutama dari sisa pakan dan kondisi lingkungan yang baik untuk bertumbuhnya bakteri dengan memonitor perbandingan karbon dan nitrogen. Kisaran perbandingan karbon dan nitrogen yang baik ditambak adalah 1:10-20 dan optimal sekitar 1: 12-16. Berikut ini gambaran kebutuhan jumlah molase yang diperlukan untuk pembentukan flok pada budidaya uang di tambak.

$\mathrm{N}=16 \% \rightarrow \mathrm{N}=4,96 \% \mathrm{x}$ Ekresi Feed Nitrogen $75 \%$

$\mathrm{N}=$ Protein pakan $\times 16 \%=30 \times 0,16=4,8 \mathrm{~N} / 100 \mathrm{~g}$ pakan

Ekresi 75\%= 75\%x 4,8 = 3,6 g N/100 pakan

$\mathrm{C} / \mathrm{N}$ yang diinginkan $(\mathrm{C} / \mathrm{N} \mathrm{1:12})=3,6 \mathrm{~g} \times 12=43,2 \mathrm{~g}$

Molase (mengandung $C=40 \%=43,2 / 0,40$ $=108 \mathrm{~mL} / 100 \mathrm{~g}$ pakan
Rendahnya pemanfaatan nitrogen pakan menyebabkan kandungan amonia-nitrogen di air menjadi berbahaya. Sedangkan bakteri dapat memanfaatkan amonia-nitrogen dengan efisien jika rasio $\mathrm{C} / \mathrm{N}$ sekitar 12-20. Sehingga kekurangan karbon dapat digunakan sumber karbohidrat tertentu seperti molase. Perkiraan kasar untuk menghitung banyaknya nitrogen dalam air tambak 1 ha kedalaman $1 \mathrm{~m}\left(10.000 \mathrm{~m}^{3}\right)$ dapat dihitung sebagai berikut: dengan asumsi Ekskresi nitrogen $=75 \%$ Kadar protein $=30 \%$ Nitrogen protein $=16 \%$ Jumlah pakan $=1 \mathrm{~kg}$, Jumlah nitrogen dalam air $=1.000 \mathrm{~g} \times 30 \% \times 16 \% \times 75 \%$ : $10.000 \mathrm{~m}^{3}$ air $=0,0036 \mathrm{mg} / \mathrm{L}$ TAN. Dibutuhkan 555,55 hari untuk mencapai $2 \mathrm{mg} / \mathrm{L}$ TAN. Namun jika pakan diberikan $100 \mathrm{~kg} / \mathrm{hari}$ maka hanya perlu waktu 5,5 hari untuk mencapai level TAN berbahaya, karena kandungan $C$ dalam karbohidrat sekitar 40\% maka dibutuhkan $=100 /$ $40 \times 0,36 \times 12=10,8 \mathrm{mg} / \mathrm{L}$ karbohidrat.

\section{PENUTUP}

Teknologi bioflok pada budidaya udang vaname intensif dapat mengurangi penggunaan pakan sekitar $10 \% 20 \%$ meningkatkan kondisi lingkungan terutama kualitas air tambak budidaya dan mempertahankan kesehatan udang sehingga produksi udang dapat ditingkatkan.

\section{DAFTAR ACUAN}

Avnimelech, Y. 1999. Carbon/nitrogen ratio as a control element in aquaculture systems. Aquaculture, 176: 227-235.

2009. Biofloc Technology, A Practical Guide Book. World Aquaculture Society, $182 \mathrm{pp}$.

and Ritvo, G. 2003. Shrimp and fish pond soils: Processes and Aquaculture. Aquaculture, 220: 549-567. 
Brune, D.E., Schwartz, G., Eversole, A.G., Collier, J.A., \& Schwedler, T.E. 2003. Intensification of pond aquaculture and high rate photosynthetic systems. Aquaculture Engineering, 28: 65-86.

Burford, M.A., Thompson, P.J., Mclntosh, R.P., Bauman, R.H., \& Pearson, D.C. 2004. The contribution of flocculated material to shrimp (Litopenaeus vannamei) nutrition in a hight-intensity zero-exchange system. Aquaculture, 232: 525-537.

De Schryver, P., Crab, R., Defoirdt, T., Boon, N., \& Verstraete, W. 2008. The basics of bio-flocss tech- nology: The added value for aquaculture. Aquaculture, 277: 125-137.

Pantjara, B. 2008. Efektivitas sumber C terhadap dekomposisi bahan organik limbah tambak udang intensif. Prosiding Seminar Nasional IV Universitas Hangtuah, Surabaya.

Verstraete, W., Schryver, P.D., Defoirdt, T., \& Crab, R. 2008. Added value of microbial life in flock. Laboratory for Microbial Ecology and Technology, Ghent Univeristy, Belgium. http://labmet.ugent.be, 43 pp. 